\author{
Anne Lise Kjar**
}

\title{
Thi kendes for ret - om lemmata og eksempler i juridisk fagleksikografi $^{* * *}$
}

\begin{abstract}
This paper will focus on some principles for lexicographical treatment of a type of fixed word combinations, which could be referred to in English as "stereotyped expressions" (in German: "Routineformeln"), more specifically stereotypes commonly and repeatedly used as stable parts of certain types of legal documents. The question is raised where word combinations of that kind should be placed in a bilingual law dictionary. Should they be placed as entries according to their status as language units? Or shold they be indicated as examples of the use of the words of which they consist? It is argued that neither of the solutions is good. In stead, stereotypes should be cited in articles describing the documents of which they are a stable part.
\end{abstract}

\section{Indledning}

De følgende overvejelser gælder en bestemt type ordforbindelse, som er udbredt i juridisk sprog: Rutineformler. Som eksempel har jeg i titlen valgt at citere en ordforbindelse: Thi kendes for ret. Den egner sig som blikfang, fordi den umiddelbart kan erkendes som en fast juridisk ordforbindelse med binding til en bestemt tekstart (en dom). Dermed har jeg allerede antydet nogle kendetegn ved rutineformler, men jeg kommer nedenfor tilbage til en nærmere bestemmelse af ordforbindelsestypens karakteristika.

Ved en leksikografisk behandling af ordforbindelser opstår spørgsmålet om ordforbindelsernes bedste placering $\mathrm{i}$ ordbogsstrukturen. Faste ordforbindelser volder særlige vanskeligheder, fordi de indtager

* Anne Lise Kjar

Caciliavej 20

DK-2500 Valby

** Artiklen er den skriftlige version af et foredrag holdt ved LEDA's generalforsamling den 10.4.1996. (LEDA er Foreningen af Leksikografer i Danmark). 
en vanskelig dobbeltposition: De er på en gang flerheder af ord, syntaktiske strukturer, dannet af mindst to enkeltord, og samtidig - i en eller anden definition - enheder i sproget. Med ordbøgers sædvanlige indretning er der som udgangspunkt to mulige placeringer for faste ordforbindelser: Angivelse som lemma, evt. sublemma, i ordbogens makrostruktur eller som eksempel i ordbogens mikrostruktur. Hvilken af kategorierne der er bedst egnet, kan ikke besvares absolut, men afhænger af ordforbindelsens art og ordbogstypen (monolingual / bilingual ordbog, fagordbog, alordbog etc. ).

Den følgende diskussion angår alene rutineformlers placering $\mathrm{i}$ bilinguale juridiske ordbøger. Jeg kommer således ikke til at tale om fagordbøger generelt, men alene om bilinguale juridiske ordbøger, der er tænkt og konciperet som praktiske hjælpemidler ved oversættelse af juridiske tekster. Det spørgsmål, jeg som udgangspunkt ønsker at belyse, lyder altså som følger:

- I hvilken af de to kategorier "lemmata" og "eksempler" kan rutineformler bedst placeres i en bilingual juridisk oversættelsesordbog?

Med til besvarelsen af dette spørgsmål hører en nærmere bestemmelse af de to kategorier. Da forskningen ikke giver nogen entydig definition, nøjes jeg i første omgang med at betegne dem som "kategorier, som forekommer i ordbøger".

Det skal fremhæves, at jeg med "bedste placering" mener bedst alene under hensyn til rutineformlers sproglige kendetegn. Jeg interesserer mig således ikke her for ordbogsbrugerens behov i forskellige opslagssituationer, dvs. den bedste placering i relation til ordbogsbrugeren. Fokus er med andre ord ikke på forholdet mellem ordbogen og dens brugere, men på forholdet mellem ordbogen og det sproglige materiale, den skal vise.

Jeg vil allerede nu foregribe, at den bedste placering af rutineformler efter min opfattelse hverken er som lemmata eller som eksempler på de indgående ords brug. Af grunde, som vil fremgå af de følgende overvejelser, synes begge disse placeringer problematiske. Derfor munder den følgende redegørelse ud i endnu et spørgsmål:

- Hvordan kan rutineformler placeres i en juridisk tosprogsordbog, når de hverken opfattes som lemmata eller som eksempler på de indgående ords brug? 


\section{Rutineformler}

Thi kendes for ret er den ordforbindelse, der er citeret i titlen. Jeg skriver her bevidst "citere", for der er det særlige ved Thi kendes for ret, at den har sin faste plads i en bestemt juridisk tekstart, en dansk dom, hvor den reproduceres hver gang, der skrives en dom på dansk. Den anvendes som en højtidelig formel for at tilkendegive over for læseren: Nu kommer dommens konklusion, og det der står i domskonklusionen skal herefter gælde. Domskonklusionen lyder også nogenlunde ens fra gang til gang, afhængigt af om parten dømmes eller frifindes, om det er en straffesag eller civilsag, om det er en dom i første eller anden instans, f.eks.:

(1) Sagsøgte bør for sagsøgers påstand fri at vare.

(2) Sagsøgte bør til sagфger betale xxx kr. med renter fra den ... at regne.

(3) Landsrettens dom bør ved magt at stande.

Hermed har vi allerede set 4 eksempler på juridiske rutineformler. ${ }^{1}$ De kan defineres som præfabrikerede ordforbindelser - ofte med syntaktisk struktur som sætninger - som reproduceres igen og igen på samme plads i bestemte juridiske tekstarter. Deres fasthed skyldes ikke, at de er semantisk omtydede som idiomatiske ordforbindelser. De udgør heller ikke nominationsenheder for et begreb i et fagligt begrebssystem som flerordstermer. ${ }^{2}$ Det er deres positionelle fiksering ${ }^{3}$, altså bindingen til en bestemt plads i en bestemt tekstart, der $\mathrm{g} ø \mathrm{r}$ at rutineformler opfattes som faste ordforbindelser. Endelig tenderer de til petrificering i en bestemt form - jfr. netop Thi kendes for ret, hvor Thi er bevaret i dag, skønt Thi ikke længere anvendes frit i betydnignen 'derfor'. Også den forældede syntaktiske form: Sagsøgte bør fri at vare er eksempel på en petrificering.

1 Udtrykket 'rutineformler' stammer fra Coulmas 1981, som definerer rutineformler som sætningsækvivalente ordforbindelser, som anvendes rutinemæssigt af et samfunds borgere i bestemte tilbagevendende situationer, primært ved mundtlig kommunikation. Det rutinemæssige kommer til udtryk på følgende måder: (1) Ordforbindelserne er forudsigelige $\mathrm{i}$ et bestemt kommunikationsforl $\varnothing \mathrm{b}$; (2) de er mere elle mindre obligatoriske i nogle bestemte situationer; (3) deres betydning og forståelighed afhænger af den situation / de situationer, de hører til og (4) de er kulturbundne (1981, 81f).

2 Jfr. (Fleischer 1982, 63 ff) om nominationsstereotyper og (Burger et al. 1982, 38) om fraseologiske termini.

3 Jfr. (Thun 1978, 66) om "Mehrwortgruppen mit textpositioneller Fixiertheit". 
Ikke alle ordforbindelser, man kan regne til denne ordforbindelsestype, er fuldstændigt stabile som Thi kendes for ret. En vis variation kan forekomme, f.eks. hedder det i frifindelsesdomme idag også: Sags $\phi g t e$ frifindes for det af sags $\phi$ ger rejste krav. Karakteristisk for dem alle er imidlertid, at de uden for den tekstart, de hører til, opløses som enheder, fordi deres status som enheder er uløseligt forbundet med deres funktion som byggesten i en bestemt tekstart.

Af de hidtil nævnte eksempler kunne man tro, at juridiske rutineformler udelukkende betragtes som ordforbindelser, med hvilke sprogbrugeren (her dommeren) foretager performative talehandlinger. Det er ofte tilfældet, men gælder ikke uindskrænket. Her er nogle andre eksempler på rutineformler i domme:

(4) Til støtte for den nedlagte påstand har X anført... (som indledning til en parts anbringende i en civildom)

(5) Rettens bemarkninger (overskrift til dommens præmisser, hvor domstolen begrunder sin afgørelse)

(6) Retten skal udtale (do.). Også i varianten:

(7) Retten skal udtale: En dommer bemarker: (...) Fire dommere bemarker: (...)

(8) Der vil vare at give dom efter stemmeflertallet (afslutning på dommens præmisser, hvor en eller flere dommere i en kollegialret afgiver dissens, er uenig med flertallet om sagens afgørelse)

(9) Straffen findes passende bestemt (i en ankedom, hvor ankedomstolen tager stilling til den forudgående domstols strafudmåling i en straffesag)

Som nævnt kan man betragte rutineformler som en slags byggesten til bestemte juridiske teksarter. De udgør således et spinkelt skelet til de pågældende tekstarter. I visse tilfælde har de juridiske sprogbrugere taget konsekvensen af brugen af præfabrikerede ordforbindelser og fastholdt ordforbindelserne i fomulartekster. Københavns byret har f.eks. som fors $\emptyset \mathrm{g}$ fået lov af Justitsministeriet til at have fortrykte domme (indlæst elektronisk). I øvrigt findes en lang række reproducerbare dokumenter i fortrykt form, således f.eks. skøder, som de følgende eksempler stammer fra.

(10) Undertegnede ... salger, skфder og endeligt overdrager herved til medundertegnede den (os) ifølge tinglyst adkomst tilhфrende ejendom matr.nr. ... beliggende ... på følgende vilkår: 
(11) Ejendommen salges / overdrages / overtages således som den nu er og forefindes og som beset af køberne

(12) Ejendommen salges / overdrages / overtages med de på ejendommen varende bygninger med grund-, mur-, nagelfast og andet tilbeh $\phi r$

(13) Ejendommen salges / overdrages / overtages med alle hegn, traer og plantninger og alt ejendommens $\phi v$ rige rette tilliggende og tilhørende

(14) Ejendommen overtages den ..., fra hvilken dato den henligger / henstår for kфbers regning og risiko i enhver henseende.

(15) Til vitterlighed om underskrifternes agthed, dateringens rigtighed samt underskrivernes myndighed:

De fleste vil nok kunne enes om, at ordforbindelser om vist i eksempel (1) til (15) bør selekteres til registrering i en bilingual juridisk oversættelsesordbog. De forekommer igen og igen i nogenlunde samme form i tekster, som juridiske oversættere sættes til at oversætte, så leksikografen kan forudse, at de vil være genstand for opslag hos den anticiperede ordbogsbruger.

Men når ordforbindelserne først er selekterede, opstår altså spørgsmålet: Er de præfabrikerede ordforbindelser lemmatiserbare eller er de snarere egnede som eksempler på de indgående ords brug?

Før det er muligt at besvare dette spørgsmål, er det nødvendigt nærmere at præcisere, hvad man i den metaleksikografiske diskussion forstår ved "lemmata" og "eksempler".

\section{Eksempler}

Jeg definerede ovenfor "eksempel" bare som en kategori, der forekommer i ordbøgers mikrostruktur. Spørgsmålet er nu, kategori i hvilken forstand? En leksikografisk kategori eller en leksikologisk? Det er omdiskuteret i metaleksikografien. Jeg synes som udgangspunkt, at det er rimeligt at betragte "eksempler" som en formel leksikografisk kategori, nemlig som den del af en ordbogsartikel som i en eller anden forstand "viser" en kontekst, og ikke stille noget krav til det sproglige materiale, som kan fungere som eksempler i en ordbogsartikel (se tilsvarende Jacobsen et al. 1989, 2784).

For mig er det ikke eksemplernes syntaktiske struktur eller udstrækning, der er afgørende. Således stiller jeg i modsætning til Bergenholtz/ Tarp ikke krav om, at et eksempel skal være mindst en sætning (1994a, 
138ff). Efter min mening kan der også være tale om valensangivelser, f.eks. bemyndige én til at gфre ngt., eller kollokationer, f.eks. indgive sin afskedsbegaring. Dermed lægger jeg mig i første omgang op af traditionen i både praktisk leksikografi og metaleksikografi.

Efter min opfattelse er det imidlertid vigtigere at fastlægge to andre forhold. Hvis eksempler "viser" en kontekst, må det for det første fastlægges, hvad det er, der skal vises i en kontekst, for det andet, hvad det vil sige at konteksten "vises".

\subsection{Eksempel på hvad?}

I tosprogsordbogen er spørgsmålet "kontekst for hvad?" ikke så tåbeligt, som det umiddelbart lyder. Der er nemlig flere muligheder: Opslagsord eller ækvivalent? Eller både-og? Rossenbeck (1991, 43f) mener både-og. Jacobsen et al. (1989, 2784) mener det samme som Zgusta (1971, 336f), nemlig at eksempler i en tosprogsordbog hører til ækvivalenten.

Efter min opfattelse kan spørgsmålet om eksemplets placering ved lemma eller ækvivalent ikke besvares, medmindre man samtidig tager stilling til, hvilke oversættelsesmetodiske problemer tosprogsordbogen skal kunne løse. I den henseende gælder andre krav til en juridisk ordbog end til en almen. Dette hænger sammen med den binding til udgangstekstens nøjagtige gengivelse, den kildesprogsorienterede eller dokumentariske oversættelsesmetode, som er nødvendig i langt de fleste situationer, hvor juridiske tekster oversættes. ${ }^{4}$ I en juridisk tosprogsordbog, der skal kunne bruges til oversættelse af juridiske dokumenter, mener jeg derfor, at eksemplet som hovedregel skal angives ved lemmaet. En ordbog med eksempler kun til ækvivalenterne ville kun kunne bruges, hvis formålet med et opslag i ordbogen blot var at finde afsæt ind i målsprogets begrebs- og tekstverden, altså at producere genuin juridisk tekst på målsproget uden binding til en tekst på udgangssproget. Det vil være en sjældent forekommende opslagssituation.

\footnotetext{
4 Valget af oversættelsesmetode ved juridisk oversættelse er en stående diskussion i forskningen. Det er ikke mit ærinde her at redegøre for de forskellige standpunkter. En udmærket indplacering af juridisk oversættelse i en større oversættelsesteoretisk ramme findes i Hansen (1995, 26ff). Se endvidere Kjær (1995).
} 
Det må altså efter min opfattelse hovedsageligt være opslagsordet, eksemplerne skal vise $\mathrm{i}$ en kontekst i den bilinguale juridiske ordbog. Om de angivne ækvivalenter også bør angives i en kontekst, afhænger af, om det er muligt at oversætte opslagsord og eksempler med genuine ækvivalenter i målsproget, eller om det er nødvendigt for nøjagtigheden at parafrasere.

\subsection{Eksemplets funktion}

Det andet spørgsmål, som må belyses i forbindelse med en fastlæggelse af kategorien eksempler lyder: Hvad vil det sige, at eksempler "viser" en kontekst? Eller med andre ord: Hvilken funktion skal eksemplet have i en juridisk tosprogsordbog? Hvorfor og hvornår skal opslagsordet vises i en kontekst?

Siden slutningen af 80 'erne er der i den metaleksikografiske litteratur skrevet en del indlæg, som belyser disse spørgsmål, se bl.a. Bergenholtz (1994), Harras (1989), Haß (1991), Hermanns (1988), Jacobsen et al. (1989), Nikula (1986). Her skal nogle hovedtræk gengives og kommenteres $\mathrm{i}$ forhold til den bilinguale juridiske ordbogs særlige karakteristika.

Eksempler i monolinguale betydningsordbøger har ifølge $\mathrm{Haß}$ (1991) to funktioner: At illustrere og at dokumentere. Det kan ikke gælde helt parallelt i en tosprogsordbog. I oversættelsesordbogen illustrerer eksemplet ikke bare opslagsordet. Det er tillige selv en oversættelsesenhed, udvalgt enten fordi det er en typisk kontekst for opslagsordet, og / eller fordi opslagsordet må oversættes anderledes i den pågældende kontekst end udenfor.

Eksemplet i den juridiske fagordbog skal heller ikke dokumentere som ved belæg eller citateksempler, dvs. tekstsegmenter med kildeangivelse, for det er ikke en forfatters kreative sprogbrug, en enkelt teksts egenart, som skal registreres med et eksempel i en juridisk oversættelsesordbog.

Eksemplet skal tjene til at hjælpe ordbogsbrugeren med at oversætte typisk juridisk sprogbrug. Eksemplet skal altså vise opslagsordet, således som det typisk anvendes i juridiske tekster på udgangssproget. Med en formulering fra Hermanns (1988) er det gode eksempel også i juridisk fagleksikografi et eksempel der virker ægte: Et eksempel hvorom sprogbrugeren med modersmålskompetence og fagviden straks 
tænker: "Ja, det er en typisk anvendelse af dette ord, sådan udtrykker jurister sig".

Jacobsen et al. (1989, 2787) stiller som krav til eksempler endvidere, at ordbogsbrugeren skal kunne generalisere ud fra eksemplet. Ordbogsbrugeren skal ud fra eksemplet kunne slutte nogenlunde sådan: "Når det er muligt at udtrykke sig som vist, må man også kunne udtrykke sig som følger ...". Den kompetente sprogbruger må med andre ord kunne foretage kommutationer og transformationer ifølge de almindelige regler for korrekt sprogbrug på grundlag af det valgte eksempel. Hvor eksemplet er kontekst til opslagsordet og ikke til ækvivalenten betyder dette med generaliserbarheden: "Når ordet i den viste kontekst, skal oversættes som angivet, må jeg kunne gå ud fra, at det i denne beslægtede kontekst skal oversættes på samme måde”.

Endelig hører det med til spørgsmålet, hvilke typer eksempler der kan anvendes. I metaleksikografien opregnes hovedsagelig tre forskellige typer eksempler: Autentiske eksempler, som er citeret fra en navngiven kilde i deres fulde længde, forkortede autentiske eksempler og endelig de såkaldte kompetenceeksempler, som er eksempler, leksikografen selv har konstrueret på grundlag af sin sprogkompetence (se f.eks. oversigten i Bergenholtz/Tarp 1994a, 138ff).

Det hedder nogenlunde samstemmende hos flere metaleksikografer, at eksempler i fagleksikografi nødvendigvis må være autentiske, evt. forkortede, se Rossenbeck (1991, 43f), Bergenholtz (1994, 431). Begrundelsen er, at leksikografen ofte mangler den nødvendige faglige indsigt til at konstruere eksempler selv. Det er efter min opfattelse en forkert konklusion. Hvis fagleksikografen har den fornødne både sproglige og faglige indsigt til overhovedet at skrive en ordbog, må han eller hun med ligeså stor ret kunne anvende kompetenceeksempler som leksikografer i øvrigt. Det kan med andre ord ikke være leksikografens kompetence, der skal være afgørende for valget af eksempeltype. Afgørende må være, om eksemplet kan vise det, det skal vise.

Så meget om "eksemplet". Det blev her defineret som en leksikografisk kategori, som opfylder følgende funktioner i den juridiske tosprogsordbog: Det viser opslagsordet i en kontekst, som udgør en typisk juridisk sprogbrug. Ud fra konteksten kan ordbogsbrugeren generalisere, således at han kan gå ud fra, at opslagsordet i andre beslægtede kontekster også kan oversættes som angivet i ordbogen. 


\section{Lemmata}

Lemmata var den anden leksikografiske kategori, vi overvejede til placering af rutineformler. Det er den kategori, som er eksplikandum i ordbogsartiklen, det som ordbogsartiklen "handler om". Man skelner i metaleksikografien mellem forskellige lemmatyper, se udførligt Bergenholtz/Tarp (1994a, 205ff). Af interesse ved behandling af ordforbindeler er især en skelnen mellem hovedlemmata, som indleder den enkelte ordbogsartikel, og sublemmata, som angives i en ordbogsartikel som en artikel i artiklen. Ordforbindelser angives i den praktiske leksikografi ofte netop som sublemmata, når de overhovedet lemmatiseres.

Kategorien lemma er ikke så omdiskuteret i metaleksikografien som eksempler. Der er bred enighed om, at leksikalske enheder af forskellig udstrækning - orddele, sammensatte og usammensatte ord og ordforbindelser - kan angives som lemmata, jfr. f.eks. Bergenholtz/Tarp (1994a, 100f). Der stilles blot generelt krav om, at lemmaet skal kunne angives i en kanonisk form, dvs. en grundform, som er renset for ad hoc tilføjelser eller ad hoc bøjninger af de indgående ord.

Men der er et spørgsmål, som trænger sig på i forbindelse med ordforbindelsers mulige lemmatisering. Hvilke betingelser skal være opfyldt, for at en ordforbindelse kan betragtes som en leksikalsk enhed, altså som en enhed i sprogets ordforråd på linie med et enkeltord? Sædvanligvis kræves i teori og praksis, at ordforbindelsen er stabil i en bestemt ordlyd, og at den udgør en semantisk ubrydelig enhed (jfr. Fleischer 1982, 67ff). Men hvilke (typer af) ordforbindelser opfylder disse kriterier og dermed betingelsen for en lemmatisering? Det er både teoretisk og praktisk vanskeligt at afgøre, og fraseologiforskningen regner således med glidende overgange fra de ordforbindelser, der er klart leksikaliserede (idiomatiske ordforbindelser), til de ordforbindelser, der er klart ikke-leksikaliserede (frie ordforbindelser), jfr. Fleischer (1982, 34).

\section{Placering af rutineformler som lemmata eller eksem- pler?}

Lad os nu vende tilbage til det spørgsmål, vi i indledningen satte os for at belyse: I hvilken af kategorierne lemma og eksempel kan juridiske rutineformler bedst placeres? 
Man kan i princippet vælge at betragte de to leksikografiske kategorier som sideordnede kategoriseringsmuligheder. Men de krav, man stiller til kategorierne, implicerer nogle krav til det sproglige materiale, som kan placeres i dem. Ifølge metaleksikografisk teori omfatter lemmata således sproglige enheder, som i en eller anden definition er langue-enheder, mens eksempler omfatter enheder, som i en eller anden definition er parole-enheder (jfr. Wolski 1989).

Anvendt på ordforbindelser betyder denne opfattelse følgende: Jo mere uforanderlig en ordforbindelses ordlyd er, og jo mere betydningen af ordforbindelsen har fjernet sig fra summen af de indgående ords betydning, jo mere tenderer ordforbindelsen til en lemmatisering. Og omvendt: Jo mere foranderlig en ordforbindelse er, og jo mindre ordforbindelsens betydning har fjernet sig fra summen af de indgående ords betydning, jo større er sandsynligheden for, at ordforbindelsen angives som eksempel på de indgående ords brug.

Men hvad betyder dette for fagleksikografiens behandling af rutineformler? Det betyder, at det er vanskeligt at placere dem i begge kategorier. Der er nemlig kendetegn ved rutineformlerne, som trækker i hver deres retning: Reproducerbarheden, det at de anvendes igen og igen i den samme ordlyd, evt. i en petrificeret form, og på det samme sted, hver gang et dokument af en bestemt art formuleres, implicerer, at de er enheder, og som enheder kan de komme på tale som lemmata.

Citatkarakteren, dette at de samtidig netop er citater fra autentiske juridiske tekster, synes til gengæld at implicere, at ordforbindelserne blot er eksempler på, hvordan de indgående ord typisk bruges i en bestemt juridisk tekstart. Denne vurdering understøttes af, at de indgående ord er anvendt i deres bogstavelige betydning. Der finder ingen egentlig betydningsændring sted som ved idiomatiske ordforbindelser, selvom der ofte vil være tale om en svag betydningsspecialisering.

Derfor synes ingen af placeringsmulighederne at være den rigtige løsning. Rutineformlerne er ikke ubrydelige betydningsenheder, men de er heller ikke variable ordforbindelser. Der er tale om ordforbindelser, der blot er faste, relativt til en bestemt plads i en bestemt tekstart, men de er ikke absolut uforanderlige, udenfor tekstarten. Deres status som enheder skyldes alene den omstændighed, at de er positionelt fikseret $\mathrm{i}$ et bestemt juridisk dokument. Men det gør dem ikke til betydningsenheder og slet ikke til langue-enheder og dermed heller ikke til typiske kandidater til et lemma. 
Men reproducerbarheden, den relative stabilitet gør dem også uegnede til at indgå i ordbogsartiklens eksempeldel. Ganske vist opfylder de to af kravene, der stilles til eksempler: De viser ord i en kontekst, og det, de viser, er en typisk kontekst. Men et eksempel skal, også selv om det er prototypisk, være et eksempel ud af mange mulige. Derfor opfylder rutineformlerne ikke det tredje krav, der stilles til kategorien eksempler, generaliserbarheden: Man kan ikke generalisere ud fra rutineformlerne.

\section{Lidt om fagleksikografisk praksis}

Men hvordan er praksis i juridisk fagleksikografi. En gennemgang af en række nyere skandinaviske tosprogordbøger røber følgende tendenser: Nogle få fagordbøger undlader helt at lemmatisere ordforbindelser og lader alle ordforbindelser, uanset type, indgå i ordbogens eksempeldel. Yderst sjældent vælges den modsatte løsning: At lemmatisere alt sprogligt materiale selekteret til ordbogen, uanset om det er enkeltord, komposita, flerordstermer, kollokationer, fagvendinger eller hele sætninger. Hovedreglen synes at være, at nogle ordforbindelsestyper lemmatiseres, mens andre angives som eksempler i ordbogsartiklen.

Wilhelm Gubba: Juridisk ordbog dansk-tysk, tysk-dansk, Gad 1993, 1995, er en ordbog med en meget dyb mikrostruktur, og en meget let makrostruktur (relativt få opslagsord). Hvilket sprogligt materiale ordbogen kvalificerer til "opslagsord", fremgår ikke af vejledningen, og om "eksempler" står der blot, at der ikke er "foretaget nogen opdeling af eksempler i sætningseksempler og kollokationer (ordforbindelser), idet alle disse medtages i opslagsordets eksempeldel" (1993, 10). Men en gennembladring af ordbogen afslører, at opslagsord her i altovervejende grad er enkeltord og komposita, mens ordforbindelser $\mathrm{i}$ så godt som alle tilfælde er angivet som eksempler. Rutineformler skal altså søges i ordbogens eksempeldel, jfr. følgende uddrag, hvor Thi kendes for ret, Retten skal udtale og Ejendommen overtages $i$ den stand den er og forefindes er angivet som eksempler på brugen af henholdsvis kende, udtale og forefinde.

Wilhelm Gubba: Juridisk ordbog dansk-tysk Gad 1993:

kende 1 (have kendskab til) kennen, 2 (bestemme) beschlieBen, 3 (fastsætte) erklären, erkennen 1. vare bekendt med (...) 
3. skyldig für schuldig erklären; ugyldig aufheben; begare beslutning kendt ugyldig die Aufhebung einer Entscheidung (eines Beschlusses) beantragen; thi $s$ for ret erkannt und verkündet; $(E F)$ generalsekretceren foreslår, at Domstolen $\sim r$ for ret der Generalanwalt beantragt, für Recht zu erkennen; Domstolen har kendt ... for ret der Gerichtshof hat ... für Recht erkannt; s skyldig $i$ en handling einer Tat (Handlung) für schuldig erklärt werden

(...)

udtale erklären, äußern (EF-ret) für Recht erkennen (EF) Rådet $\sim r$ sig der Rat gibt eine Stellungnahme ab; efter at parterne har haft lejlighed til at sig nach Anhörung der Parteien; retten skal das Gericht befindet; das Gericht stellt fest; vare forpligtet til at $\sim$ sig zur Äußerung verpflichtet sein (...)

forefinde 1 (bestå) vorfinden, 2 (konstatere) feststellen, 3 (foreligge) vorhanden sein

1. ejendommen overtages $i$ den stand den er og $\sim$ das Grundstück wird wie es steht und liegt übernommen (... übernommen wie es steht und liegt); die Übernahme des Grundstücks erfolgt im gegenwärtigen Stand; overtage genstande, som de er og $\sim s$ Werte im gegenwärtigen Stand übernehmen; $\sim s$ til afbenyttelse (f.eks. bekendtgфrelse) zur Einsicht ausliegen

(...)

Torben Henriksen: Juridisk ordbog dansk-tysk, Gad 1991, er det eneste eksempel, jeg har set på den modsatte fremgangsmåde: En udstrakt grad af lemmatisering af ordforbindelser: Ordbogen er bemærkelsesværdig ved sin meget tunge makrostruktur. Alle enkeltord og "ordsammenstillinger", som forfatteren opfatter som termer, angives som opslagsord ("indgangstermer"). Til gengæld mangler ordbogen helt en eksempeldel i mikrostrukturen. Som "indgangstermer" angives f.eks. følgende ordforbindelser:

\section{Torben Henriksen: Juridisk ordbog spansk - dansk. Gad 1991:}

agente en todo momento el mayor empeño en desenvolver / ampliar las ventas de los productos del mandante dentro del territorio asignado, poner el påhvile agenten til enhver tid med flid og interesse at organisere / at virke for afsætningen / salget af agenturgiverens varer inden for kontraktområdet agente, transmitir / transladar / dar traslado de pedidos al principal un indsende ordrer (: en agent) til agenturgiveren 
cargas familiares, contribuir al levantamiento de las bidrage til afholdelse af familiens udgifter / bidrage til familiens underhold

sentencia el juez, (pronunciar), mandar y firmar por una bestemme (således) ved en dom, som herved underskrives (: retten) [proc.r., Sp.] (...)

voluntad con arreigo a las siguientes cláusulas: ..., otorgar su última bestemme som sin sidste vilje: ...

Uden at kunne spansk er det muligt på grundlag af de angivne ækvivalenter at slutte sig til, at "indgangstermerne" her er rutineformler hørende til bl.a. agentkontrakter, domme og testamenter.

Også i Helle Pals Frandsen: Juridisk ordbog engelsk-dansk, Gad 1994, er en del rutineformler lemmatiseret. Men her indgår rutineformler også i vid udstrækning i ordbogens eksempeldel. Kriteriet for, om den ene eller den anden løsning vælges, fremgår ikke af ordbogens vejledning, men det synes at spille en rolle, om ordbogen indeholder andre oplysninger til det ord, der er alfabetiseret under. Jfr. følgende eksempler:

Helle Pals Frandsen: Juridisk ordbog engelsk-dansk. Gad 1994:

(a) Eksempler på ordforbindelser, som er lemmatiseret (hovedlemmata):

basic needs of the debtor and his family, satisfying the fog.r. [debitors ret til at beholde visse genstande, der er] nødvendige for at opretholde et beskedent hjem og en beskeden levefod [dvs. = trangsbeneficiet $]$

BE IT ENACTED by the Queen's most Excellent Majesty, by and with the advice and consent of the Lords Spiritual and Temporal, and Commons, in this present Parliament assembled, and by the authority of the same, as follows:[ $\rightarrow$ enacting clause $i$ engelske love svarende til „VI MARGRETHE DEN ANDEN, af Guds Nåde Danmarks Dronning, gør vitterligt: Folketinget har vedtaget og Vi ved Vort samtykke stadfæstet følgende lov:]

belief, to the best of his knowledge and efter hans bedste overbevisning 
(b) Eksempler på rutineformler, som er angivet som eksempler:

court subst. domstol, ret; retssal

ex. the court is in session retten er sat; may (it) please the court [indledningsformular ved mundtlig forelaggelse for retten] svarer til: "Høje Ret"

(...)

-, (in) open (for) åbne døre, (i) offentligt retsmøde, (i) offentlig retsforhandling

(...)

ex. the case was heard in open court sagen foretoges $\mathrm{i}$

offentligt retsmøde;

Mellemløsningen, en lemmatisering af nogle ordforbindelser og en angivelse af andre som eksempler, ses i Sandro Nielsen: Engelsk-dansk basisordbog, Munksgaard 1993. Ifølge vejledningen lemmatiseres her foruden enkelte ord og forkortelser også sammensætninger bestående af to eller flere ord. Ved en gennembladring af ordbogen kan man konkludere, at der med sammensætninger af ord menes flerordstermer, mens rutineformler placeres i eksempeldelen som "fraseangivelser". Jfr. til illustration ordbogens artikler vedr. "court":

county court $s \rightarrow \S 10$

court $s$ institution, der af samfundet er sat til at afgøre retssager efter gældende ret og regler om retspleje

ret

[] appear before the $\infty$ give møde i retten; if it pleases the $\infty$ med rettens tilladelse; it was not proved to the satisfaction of the $\infty$ that retten fandt det ikke godtgjort at; the $\infty$ will lean against the stipulation retten er utilbøjelig til at acceptere bestemmelsen = domstol

Court of Appeal $s \rightarrow \S 2 ; \S 14$

Court of Protection $s$ afdeling af High Court, der er ansvarlig for forvaltningen af mentalt syge personers formuer $\approx$ formynderdomstol

$\rightarrow$ High Court

Om en ordforbindelse lemmatiseres eller angives som eksempel på et lemmas brug, afgøres i praksis nok oftest af, om ordbogsforfatteren opfatter en given juridisk ordforbindelse som en "term" (jfr. f.eks. Torben Henriksen: "Ved term forstås ikke alene et enkelt ord, men også sammenstillinger af ord."). "Term" defineres i vejledningerne i øvrigt 
ikke nærmere, men det er nærliggende at antage, at leksikograferne implicit stiller som krav, at der skal være tale om benævningsenheder for et juridisk begreb - altså lægger terminologilærens definition til grund.

Også i praksis synes det derfor i mange tilfælde at være leksikaliseringskravet, der afgør om en ordforbindelse lemmatiseres eller ej. Det er altså igen langue / parole-dialektikken, som gemmer sig bag ordbogsforfatternes valg.

\section{En tredje løsning: Et forslag til overvejelse}

Problemet er imidlertid, at den Saussure'ske inddeling af sprogets eksistensformer i langue og parole er utilstrækkelig til beskrivelse især af fagsprog. Derfor er ordbøgernes tvedeling i opslagsord og eksempler, som afspejler langue-/ parole-polerne også utilstrækkelig.

I erkendelse af, at sproget omfatter andre eksistensformer end det abstrakt mulige langue og det konkret realiserede parole, er der senere $\mathrm{i}$ den strukturalistiske litteratur indført en mellemform, sprognormen, om det typiske i sproget (Coseriu 1971, v. Polenz 1973). Denne norm er langt mere relevant til beskrivelse af det juridiske fagsprog generelt og rutineformler specielt (se nærmere Kjær 1990).

Jeg vil dog ikke som løsning på problemet med placering af rutineformler i de eksisterende ordbøger foreslå, at der indføres en tredje leksikografisk kategori svarende til sprognormen. Udvejen ligger snarere i et brud med opfattelsen af ordbøger, som bøger, der viser ord og ordforbindelser, men ikke tekster.

Fagordbøger bygger sædvanligvis i både teori og praksis på faglige begrebssystemer. Der registreres fagord og fagvendinger, oftest i alfabetisk rækkefølge. I juridisk sprog angives deres tilhørsforhold til et retsområde, og der tilføjes i bedste fald en henvisning til en encyklopædisk gennemgang et andet sted i ordbogen, som råder bod på den kaotiske alfabetiske listning af fagordene og giver en systematisk redegørelse for dem som benævnelser for faglige begreber.

Fagtekster indgår derimod højst som det korpusmateriale, der danner grundlag for selektion af materiale til ordbogens artikler. Men de omtales ikke i ordbogsartiklerne, der henvises ikke til dem, de medtages ikke i ordbøgerne. 
Men netop ved ordbøgernes behandling af rutineformler er dette fravær af fagtekster uheldigt. Som vi så ovenfor, er rutineformler jo netop karakteriseret ved at være faste bestanddele af bestemte juridiske tekstarter.

Når f.eks. Thi kendes for ret anføres i en tosprogsordbog som eksempel på brugen af kende, mangler der som minimum en glosse om, at det er en rutineformel i en dom, som indikerer domskonklusionen. Tilsvarende mangler som glosse til rutineformlen Ejendommen salges således som den er og forefindes og som beset af $k \phi b e r$, når den anføres som eksempel på forefindes, i det mindste en oplysning om, at ordforbindelsen hører hjemme som fast bestanddel af et skøde, og at det er denne tekstdel, som er anført og foreslået oversat som vist.

Men man kunne gå endnu mere radikalt til værks. I virkeligheden hører ordforbindelsen Ejendommen salges ... slet ikke naturligt hjemme under stikordet "forefindes", men under "skøde". Man kunne derfor under opslagsordet "skøde" opliste ikke kun eksempler på brugen af ordet $s k \phi d e$, men også de rutineformler, som dokumentet 'skøde' består af. Alternativt kunne man ud over den encyklopædiske indledning, som er en udmærket udvidelse af den traditionelle fagordbog, inspireret af Wiegands forslag om genindførelse af albogen (Wiegand 1988), have en dokumentsamling tilknyttet ordbogen og henvise til denne samling fra artiklerne.

\section{Konklusion}

Jeg satte mig i indledningen for at belyse spørgsmålet om rutineformlers bedste placering i bilinguale juridiske oversættelsesordbøger - som lemmata eller som eksempler - og er nu nået til vejs ende i mine overvejelser. Det var ikke min hensigt at komme med en endegyldig løsning på problemet eller at give konkrete anvisninger på, hvordan en alternativ placering af rutineformler kunne udmøntes i praksis. Alligevel forsøger jeg at konkludere:

Thi kendes for ret:

Rutineformler bør hverken angives som lemmata eller som eksempler på de indgående ords brug. De bør angives som det de er: Byggesten til juridiske tekster. 


\section{Litteraturliste}

\subsection{Primærlitteratur}

Frandsen, Helle Pals: Juridisk ordbog engelsk - dansk. Gad 1994.

Gubba, Wilhelm: Juridisk ordbog dansk-tysk Gad 1993.

Gubba, Wilhelm: Juridisk ordbog tysk-dansk. Gad 1995.

Henriksen, Torben: Juridisk ordbog spansk - dansk. Gad 1991.

Hjelmblink, Steen: Retsplejeordbog. Munksgaard 1991.

Lind, Åge: Norsk-engelsk juridisk ordbog. Sivilrett og strafferett. Bedriftsøkonomenes Forlag 1992.

Nielsen, Sandro: Engelsk-dansk juridisk basisordbog. Munksgaard 1993.

Parsenow, Günter: Fachwörterbuch für Recht und Wirtschaft Schwedisch / Deutsch Deutsch / Schwedisch. Carl Heymanns 1985.

Simonnæs, Ingrid: Norsk-tysk juridisk ordbog. Fakbokforlaget 1994.

\subsection{Sekundærlitteratur}

Bergenholtz, Henning / Tarp, Sven (red.) (1994a): Manual i fagleksikografi. Udarbejdelse af fagordbøger. Problemer og løsningsforslag. Herning: systime 1994.

Bergenholtz, Henning / Tarp, Sven (1994b): Mehrworttermini und Kollokationen in Fachwörterbüchern. In: Burkhard Schaeder / Henning Bergenholtz (Hrsg.): Fachlexikographie. Fachwissen und seine Repräsentation in Wörterbüchern. Tübingen: Narr 1994 (Forum für Fachsprachen-Forschung 23).

Bergenholtz, Henning (1994): Beispiele in Fachwörterbüchern. In: Burkhard Schaeder / Henning Bergenholtz (Hrsg.): Fachlexikographie. Fachwissen und seine Repräsentation in Wörterbüchern. Tübingen: Narr 1994 (Forum für FachsprachenForschung 23).

Burger, Harald et al. (1982): Handbuch der Phraseologie. Berlin, New York: de Gruyter 1982.

Chaffey, Patrick Nigel (1993): Problemer i forbindelse med tospråklig juridisk leksikografi. In: Ruth Vatvedt Fjeld (red.): Nordiske Studier i Leksikografi I. Rapport fra Konferanse om leksikografi i Norden 28.-31. mai 1991. Oslo 1993, 501-508.

Coseriu, Eugenio: System, Norm und 'Rede' (1971). In: Uwe Petersen (Hrsg.): Eugenio Coseriu: Sprache. Strukturen und Funktionen. XII Aufsätze zur allgemeinen und romanischen Sprachwissenschaft. 2. Aufl. Tübingen: Narr 1971. (Tübinger Beiträge zur Linguistik). 53-72.

Coulmas, Florian (1981): Routine im Gespräch. Zur pragmatischen Fundierung der Idiomatik. Wiesbaden 1981.

Fleischer, Wolfgang (1982): Phraseologie der deutschen Gegenwartssprache. Leipzig: Bibliographisches Institut 1982. 


\section{4}

Gülich, Elisabeth (1988): Routineformeln und Formulierungsroutinen. Pragmatische Phraseologismen aus kommunikativer Sicht. Jahrestagung 1988 des Instituts für deutsche Sprache. (Upubliceret foredragstekst).

Hansen, Gyde (1995): Einführung in das Übersetzen. København: Handelshøjskolen 1995.

Harras, Gisela (1989): Zu einer Theorie des lexikographischen Beispiels. In: F. J. Hausmann et al. (Hrsg.): Wörterbücher. Dictionaries. Dictionnaires. Ein internationales Handbuch zur Lexikographie. Erster Teilband. Berlin, New York: de Gruyter 1989ff, 607-614.

Haß, Ulrike (1991): Textkorpus und Belege. Methodologie und Methoden. In: Gisela Harras et al. (Hrsg.): Wortbedeutungen und ihre Darstellung im Wörterbuch. Berlin, New York: de Gruyter 1991, 212-292.

Hermanns, Fritz (1988): Das lexikographische Beispiel. Ein Beitrag zu seiner Theorie. In: Gisela Harras (Hrsg.): Das Wörterbuch. Artikel und Verweisstrukturen. Jahrbuch 1987 des Instituts für deutsche Sprache. Schwann 1988, 161-195.

Jacobsen, Jane Rosenkilde / Manley, James / Hjørnager Pedersen, Viggo (1989): Examples in the Bilingual Dictionary. In: F. J. Hausmann et al. (Hrsg.): Wörterbücher. Dictionaries. Dictionnaires. Ein internationales Handbuch zur Lexikographie. Dritter Teilband. Berlin, New York: de Gruyter 1989ff, 2782-2789.

Kempcke, Günter (1994): Zur Darstellung der kommunikativen Wendungen in den gegenwartssprachlichen Wörterbüchern des Deutschen. In: Sandig, B. (Hg.): EUROPHRAS 92. Tendenzen der Phraseologieforschung. Universitätsverlag Brockmeyer 1994. (Studien zur Phraseologie und Parömiologie 1), 303-314.

Kjær, Anne Lise (1990): Normbetingede ordforbindelser i tysk juridisk sprog. København 1990. (ARK 56).

Kjær, Anne Lise (1995): Vergleich von Unvergleichbarem. Zur kontrastiven Analyse unbestimmter Rechtsbegriffe”. In: Kromann, H.-P. $(\dagger) /$ Kjær, A.L. (Hrsg.): Von der Allgegenwart der Lexikologie. Kontrastive Lexikologie als Vorstufe zur zweisprachigen Lexikographie. Tübingen: Niemeyer 1995, (Lexikographica, Series Maior. 66), 39-56.

Kühn, Peter (1986): Zur Bedeutungsbeschreibung von Rutineformeln in Wörterbüchern. In: Albrecht Schöne (Hrsg.): Kontroversen, alte und neue. Akten des VII. Internationalen Germanisten-Kongresses Göttingen 1985. Band 3: Textlinguistik contra Stilistik? Wortschatz und Wörterbuch. Hrsg. v. Marga Reiß et al.. Tübingen: Niemeyer 1986, 223-227.

Kühn, Peter (1994): Pragmatische Phraseologie. Konsequenzen für die Phraseographie und Phraseodidaktik. In: Sandig, B. (Hrsg.:) EUROPHRAS 92. Tendenzen der Phraseologieforschung. Universitätsverlag Brockmeyer 1994. (Studien zur Phraseologie und Parömiologie 1), 411-428.

Nikula, Henrik (1986): Wörterbuch und Kontext. Ein Beitrag zur Theorie des lexikographischen Beispiels. In: Albrecht Schöne (Hrsg.): Kontroversen, alte und neue. Akten des VII. Internationalen Germanisten-Kongresses Göttingen 1985. Band 3: 
Textlinguistik contra Stilistik? Wortschatz und Wörterbuch. Hrsg. v. Marga Reiß et al. Niemeyer 1986, 187-192.

Pankow, Christiane / Salminen, Olli (1987): Routineformeln im finnisch-deutschen Spracherwerb - eine Forschungsaufgabe. In: Korhonen, J. (Hrsg.): Beiträge zur allgemeinen und germanistischen Phraseologieforschung, Oulu 1987. (Veröffentlichungen des Germanistischen Instituts 7), 237-243.

Polenz, Peter von (1973): Sprachkritik und Sprachnormenkritik. In: G. Nickel (Hrsg.): Angewandte Sprachwissenschaft und Deutschunterricht. München 1973.

Rossenbeck, Klaus (1991): Zwei- und Mehrsprachige Fachwörterbucher - Prolegomena zu Theorie und Praxis der Fachlexikographie. In: Hermes 7, 1991, 29-52.

Wolski, Werner (1989): Das Lemma und die verschiedenen Lemmatypen. In: F. J. Hausmann et al. (Hrsg.): Wörterbücher. Dictionaries. Dictionnaires. Ein internationales Handbuch zur Lexikographie. Erster Teilband. de Gruyter 1989ff, 360-371.

Zgusta, Ladislav (1971): Manual of Lexicography. Mouton 1971. 